\title{
Stimulation of development in vitro by platelet-activating factor receptor ligands released by mouse preimplantation embryos
}

\author{
N. R. Stoddart*, A. E. Wild and T. P. Fleming ${ }^{\dagger}$ \\ Department of Biology, School of Biological Sciences, University of Southampton, Bassett Crescent East, \\ Southampton SO16 7PX, UK
}

\begin{abstract}
Previous reports have demonstrated that culture of mouse preimplantation embryos at high density stimulates their rate of development. The molecular basis of this phenomenon was investigated. Culture of embryos from the four-cell stage at high density in normal medium, or at low density either in embryo-conditioned medium or medium containing plateletactivating factor (PAF), significantly advanced the timing of compaction, initiation of cavitation and/or completion of zona hatching, and also increased the number of cells in blastocysts. In contrast, Lyso-PAF, an inactive metabolite of PAF, and Enantio-PAF, an enantiomer of PAF, did not have a stimulatory effect at low embryo density, but did not inhibit the stimulation of development at high embryo density. The stimulatory effect of culture at high density was inhibited in the presence of either CV-3988 or SDZ 64-412, two structurally distinct competitive PAF-receptor antagonists, while the development rate at low density was not affected. We conclude that an embryo-derived factor related to PAF is secreted by blastomeres during in vitro culture and acts in a receptor-mediated manner to stimulate the rate of development.
\end{abstract}

\section{Introduction}

Several reports have indicated that culture of early mouse embryos in vitro at high density (as measured by number of embryos per unit volume of medium) stimulates their rate of development (Wiley et al., 1986; Paria and Dey, 1990; Lane and Gardner, 1992; O'Neill, 1994). Although these densitydependent effects are thought to be mediated by endogenous factors released by the embryo, no direct evidence for the involvement of specific molecules has been forthcoming. Lane and Gardner (1992) have, however, proposed embryo-derived platelet-activating factor (EPAF) as a potential factor.

EPAF may be homologous to platelet-activating factor (PAF; 1-O-alkyl-2-acetyl-sn-glycero-3-phosphocholine, Demopoulos et al., 1979; reviewed by Harper, 1989; Chao and Olson, 1993) and is thought to be composed of a mixture of predominantly $\mathrm{C}_{16}$ and $\mathrm{C}_{18}$ PAF-like molecules coupled to one or more regulatory molecules (reviewed by Adamson et al., 1991). EPAF is synthesized by two-cell mouse embryos (Wells and O'Neill, 1992) and secreted by the cleavage stages of several mammalian species including mice, rabbits, sheep and humans (O’Neill, 1985; Collier et al., 1988, 1990; O'Neill et al., 1989; Battye et al., 1991; Minhas et al., 1993; Ripps et al., 1993). Exogenous PAF is known to exert a range of specific effects on early mouse embryos including stimulation of oxidative metabolism of energy substrates (Ryan et al., 1989, 1990a),

\footnotetext{
*Present address: NURTURE, Department of Obstetrics and Gynaecology University Hospital, Queen's Medical Centre, Nottingham NG7 2UH. UK.

${ }^{+}$Correspondence and reprint requests.

Received 15 December 1995.
}

mitosis (Roberts et al., 1993; O'Neill, 1994), number of cells in blastocyst and implantation rate (Ryan et al., 1990b). PAF also appears to increase placental, but not fetal, mass (Ryan et al., 1990b). In addition, it has been shown that PAF-mediated stimulation of certain processes in early development can be blocked by anti-PAF antibody (Roudebush et al., 1995a) and specific competitive antagonists of the PAF receptor (Ryan et al., 1990a, b; Spinks et al., 1990; Roberts et al., 1993), indicating a receptor-mediated mechanism. Thus EPAF or other PAF-receptor ligands and their receptors have the potential to constitute a functional ligand/receptor circuit in the mouse preimplantation embryo.

In the present study, we investigated whether PAF activity could explain the stimulation of embryo development during culture at high density. Our results indicate that this phenomenon is caused by the release of a PAF-like factor by blastomeres which acts in a receptor-mediated reaction to promote development.

\section{Materials and Methods}

\section{Embryo collection, culture and manipulation}

MF1 female mice (3-4-week-old, Olac-derived, Southampton University Animal House) were superovulated by i.p. injections (5 iu) of pregnant mares' serum gonadotrophin (PMSG, Folligon; Intervet, Cambridge) and then hCG (Chorulon; Intervet) given $46-48 \mathrm{~h}$ apart, and then mated with MF1 males before collection and culture of embryos in M2 + BSA and M16 + BSA media, respectively, as described by Fleming et al. 
(1991). Embryos were collected either at the early to midfour-cell stage (52-56 h after the hCG injection) or as eight-cell embryos (66-67 h after the hCG injection). Embryos used for assessment of the effects of culture at high density were cultured from the early four-cell stage (or eight-cell/morula stage) in $25 \mu \mathrm{l}$ drops of M16 + BSA under oil either in groups of ten (0.4 embryos $\left.\mu l^{-1}\right)$ or individually (0.04 embryos $\left.\mu l^{-1}\right)$. This protocol was also used for collection of embryos in M2 and M16 supplemented with $6 \mathrm{mg}$ polyvinyl pyrrolidone $\mathrm{ml}^{-1}$ (PVP, Fisons, Loughborough), an inert polymer to replace BSA. 'Standard' embryo-conditioned medium was produced by culture of ten freshly collected four-cell embryos in $25 \mu \mathrm{l}$ drops of $\mathrm{MI6}+\mathrm{BSA}$ under oil for $48 \mathrm{~h}$ to the mid-blastocyst stage before removal of embryos. Alternatively, 20 embryos cultured for only $24 \mathrm{~h}$ were used for production of 'concentrated' conditioned medium in certain experiments. Non-conditioned control medium was prepared at the same time as conditioned medium and consisted of similar drops incubated at $37^{\circ} \mathrm{C}$ but without embryos. Embryos were cultured individually from the four-cell stage in $25 \mu \mathrm{l}$ drops of conditional medium or control medium. Four-cell embryos at high or low density were also cultured in M16 + BSA containing PAF or related analogues and receptor antagonists (see below). In all cases, embryos were scored for morphological development or number of cells at the appropriate culture times.

Removal of the zona pellucida was achieved by a short $(15-20 \mathrm{~s})$ incubation in warm $\left(37^{\circ} \mathrm{C}\right)$ acid Tyrodes solution (Nicolson et al., 1975) or by incubation in pronase $(0.5 \% \mathrm{w} / \mathrm{v}$, $5 \mathrm{~min}, 37^{\circ} \mathrm{C}$; BDH Ltd, Poole) in PBS (Oxoid, Basingstoke, Hants) containing PVP (10 $\mathrm{mg} \mathrm{ml}^{-1}$ ).

\section{Special reagents}

Hexadecyl $\left(\mathrm{C}_{16}\right)$ and octadecyl $\left(\mathrm{C}_{18}\right)$ platelet-activating factor (PAF) (08-74-0001 and 08-74-0002, respectively), Enantio-PAF $C_{16}$ (08-74-0006) and Lyso-PAF C ${ }_{16}$ (08-74-0003) were obtained from Calbiochem-Novabiochem (UK) Ltd (Nottingham). CV-3988 (rac-3-(N-n-octadecyl-carbamoyloxy)2-methoxypropyl-2-thiazolioethylphosphate, P-5786) was obtained from Sigma (Poole) and SDZ 64-412 (HUL-614; 5-[4'-(3,4,5-trimethoxyphenylethyl)phenyl]-2,3-dihydro-imidazo[2, I-a]isoquinoline hydrochloride) was a generous gift from D.A. Handley (Sandoz Research Institute, East Hanover, NJ). All stocks other than SDZ 64-412 and CV-3988 were dissolved in ethanol at a concentration of $16.9 \mathrm{mmol}^{-1}$ and stored as aliquots at $-20^{\circ} \mathrm{C}$. Stock CV-3988 was dissolved either in dimethylsulfoxide (DMSO; Sigma) or ethanol at a concentration of $8.45 \mathrm{mmol} \mathrm{l}^{-1}$ before freezer storage. Stock SDZ 64-412 was stored in powder form at $4^{\circ} \mathrm{C}$ and dissolved in $\mathrm{M} 16+\mathrm{BSA}$ at a concentration of $1.69 \mathrm{mmol}^{-1}$ and stored for up to $\mathrm{I}$ week at $4^{\circ} \mathrm{C}$ before dilution in medium to $10 \mu \mathrm{mol} \mathrm{l}{ }^{-1}$ for embryo culture. Working solutions of the remaining stock solutions were prepared immediately before use. Equal volumes ( $1 \mu \mathrm{l}$ ) of stock solutions (or ethanol for controls) were transferred to siliconized Eppendorf tubes, the ethanol was evaporated off under vacuum at room temperature for $15 \mathrm{~min}$, and the residue resuspended in $1.69 \mathrm{ml}$ of M16 + BSA to give final concentrations of $5 \mu \mathrm{mol} \mathrm{I}^{-1}(\mathrm{CV}-3988)$ or $10 \mu \mathrm{mol} \mathrm{l}^{-1}$ (other reagents). When CV-3988 was used from a DMSO stock, the control medium contained an identical volume of DMSO $\left(0.6 \mu \mathrm{l} \mathrm{ml}{ }^{-1}\right)$. The PAF and Lyso-PAF media were further diluted with control medium to give working concentrations of $0.5 \mu \mathrm{mol} 1^{-1}$ (analysis of morphological development) and $0.2 \mu \mathrm{mol} \mathrm{l}^{-1}$ (analysis of number of cells).

\section{Scoring of embryos for rate of morphological development}

Embryos were examined at intervals during culture using a Wild Heerbrugg stereomicroscope equipped with $37^{\circ} \mathrm{C}$ heated stage for determination of morphological development. Embryos were scored for compaction (eight-cell stage), initiation of cavitation (nascent blastocoelic cavity; approximately 32-cell stage) and complete hatching from the zona pellucida. Embryos from each treatment were removed for analysis of number of cells at different time points.

\section{Scoring of embryos for number of cells}

Two methods were used. Differential labelling of blastocyst inner cell mass and trophectoderm nuclei in situ was achieved by the method of Handyside and Hunter (1984) with modifications. Blastocysts were removed from culture 96-105 h after hCG injection, freed of their zonae pellucidae using acid Tyrodes, washed twice in $\mathrm{M} 2+\mathrm{BSA}$, and incubated at room temperature in heat-inactivated rabbit anti-mouse spleen-cell antiserum (RAMS; $15 \mathrm{~min}$ ) diluted 1:10 with $\mathrm{M} 2+\mathrm{BSA}$ and vigorously washed through six changes of $\mathrm{M} 2+\mathrm{BSA}$. Embryos were transferred to a 1:10 dilution of guinea-pig complement serum (Low-Tox, Cedar Lane laboratories; CL 4051, Vector Labs, Peterborough) in $\mathrm{M} 2+\mathrm{BSA}$ containing propidium iodide (Sigma) at $10 \mu \mathrm{g} \mathrm{ml}-1$ and incubated at $37^{\circ} \mathrm{C}$ for $10-15 \mathrm{~min}$. During this time, blastocysts were periodically examined for degree and evenness of lysis of outer cells and were removed when all outer cells were visibly swollen. Blastocysts were washed briefly in $\mathrm{M} 2+$ PVP before fixing and labelling in bisbenzimide (Hoechst 33258; Sigma) at $20 \mu \mathrm{g} \mathrm{ml}^{-1}$ in absolute alcohol overnight (or up to a week if necessary) at $4^{\circ} \mathrm{C}$. Labelled blastocysts were washed for at least $30 \mathrm{~min}$ in absolute alcohol before mounting and examination. Blastocysts were mounted individually on microscope slides in drops of glycerol and any alcohol transferred allowed to evaporate before the coverslip was applied. Specimens were viewed within 2 days on a Leitz Diaplan fluorescence microscope fitted with appropriate filter systems. Each blastocyst was examined at different planes of focus. Trophectoderm nuclei (outer cells) appeared red/orange under green light excitation and pink under UV light. Nuclei of the inner cell mass appeared blue under UV light and unstained under green light excitation. The number of outer and inner cells was determined by counting nuclei after gentle squashing and spreading of embryos using a pencil eraser to apply downward pressure on the coverslip.

An alternative method for determination of total number of cells in blastocysts involved removal of the zona using pronase, washing in $\mathrm{M} 2+\mathrm{PVP}$ and fixation in absolute alcohol containing bisbenzimide $\left(50 \mu \mathrm{g} \mathrm{ml}^{-1}\right.$, overnight at $\left.4^{\circ} \mathrm{C}\right)$ before washing in absolute alcohol $(30 \mathrm{~min})$, mounting on slides 
in glycerol and viewing under UV light (all nuclei appeared blue).

\section{Statistical analyses}

The proportions of embryos reaching various morphological stages at defined culture times were tested for significance using log linear analysis (SAS, 1988). This method was also used to control for variation between replicates. In all cases, variation between replicates had no significance on the interactions tested $(P>0.6)$. Differences in mean number of cells were tested for significance by Student's $t$ test (variances not assumed to be equal, see Sokal and Rohlf, 1973).

\section{Results}

\section{Effect of culture density on embryonic development}

Embryos were cultured from the four-cell stage in M16 + BSA at high (ten embryos per $25 \mu \mathrm{l}$ ) or low (one embryo per $25 \mu \mathrm{l}$ ) culture densities. Embryos at high density completed compaction $(P<0.01)$, initiated cavitation $(P<0.05)$ and hatched from their zonae $(P<0.01)$ faster than embryos at low density, although no difference was detected in the timing of the four- to the eight-cell transition $(P>0.05$; Fig. Ia). High density culture also significantly increased the total number of cells in blastocysts $(P<0.01)$ as shown in the number of cells in both the trophectoderm $(P<0.02)$ and inner cell mass $(P<0.01)$ compared with low density culture (Fig. Ic). Embryos collected and cultured at high density from the eight-cell/morula stage cavitated at a similar time to those cultured at low density $(P>0.05)$ but hatched from their zonae at a faster rate $(P<0.01$; Fig. Ib). The stimulatory effect of high density culture on cavitation rate was also evident when embryos were cultured from the four-cell stage in protein-free medium (M16 + PVP; P<0.001; Fig. Id).

\section{Effect of embryo-conditioned medium on embryo development}

Embryos cultured from the four-cell stage at low density in standard conditioned medium initiated cavitation $(P<0.05)$ and hatched from their zonae $(P<0.001)$ at a faster rate than

Fig. 1. Effect of culture density on rate of development and number of cells in the blastocysts of mice. Embryos, cultured at high ( $\mathbf{\omega}$; ten embryos per $25 \mu \mathrm{l}$ medium) or low density ( $\square$; one embryo per $25 \mu \mathrm{l}$ medium) in M16 + BSA media from the four-cell stage (a, c) or from the eight-cell stage (b) were assessed at specified times after hCG injection for stage of development $(\mathrm{a}, \mathrm{b})$ or, at $96 \mathrm{~h}$ after hCG injection, for the number of cells in the inner cell mass (ICM), trophectoderm (TE) and the total within blastocysts after differential nuclear labelling (c). Effect of culture density on rate of development following culture from the four-cell stage in M16 + PVP (protein-free medium) is shown in (d). Values are means of three (a, b, d) or two (c) independent experiments and the number of samples is shown in parentheses. $* P<0.05, * * p<0.02, * * * P<0.01, \quad N S=$ not significantly different. embryos cultured in control medium (Fig. 2). Embryos collected and cultured at low density in concentrated conditioned medium from the eight-cell/morula stage for $24 \mathrm{~h}$ had significantly increased numbers of cells in the blastocyst $(P<0.05)$ compared with embryos cultured in control medium (Fig. 2). These results indicate that embryo-conditioned medium
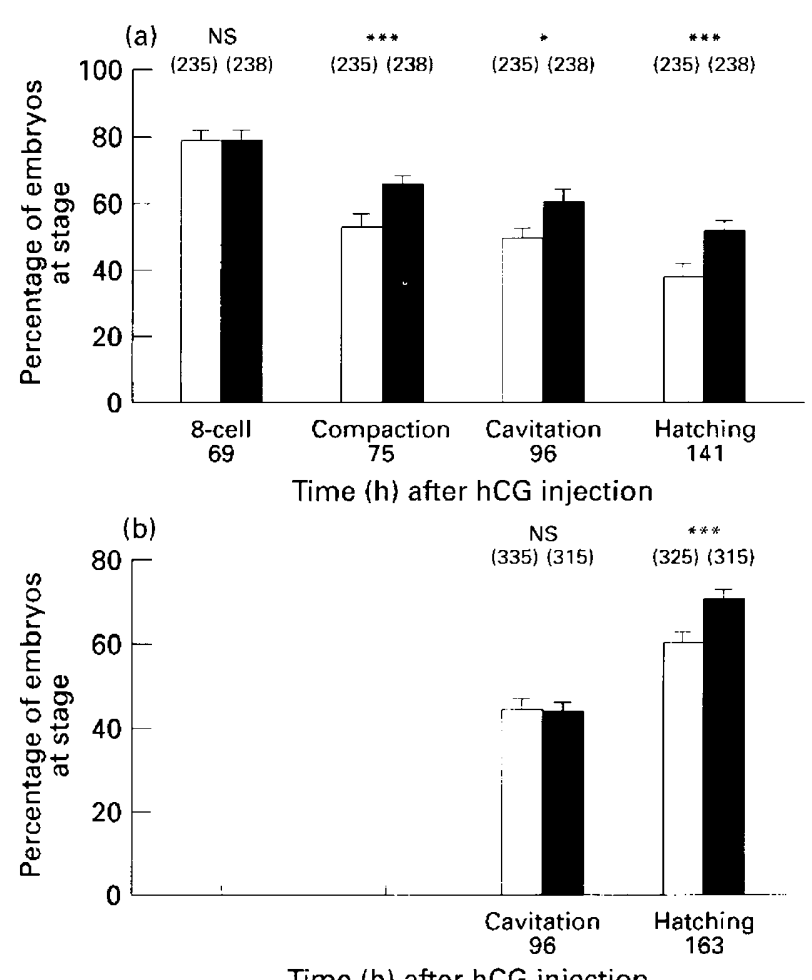

Time (h) after hCG injection
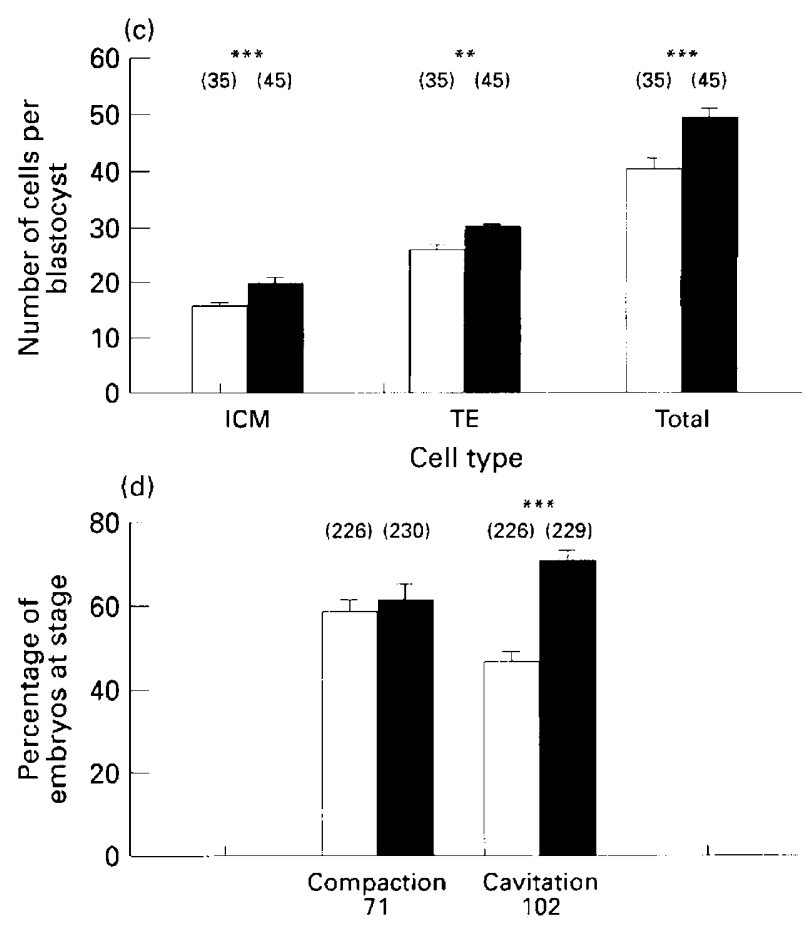

Time (h) after hCG injection 


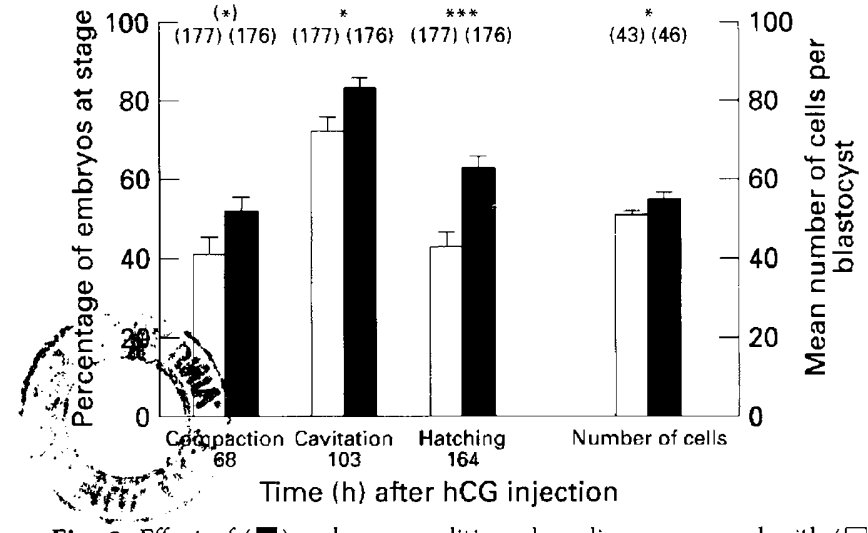

Fig. 2. Effect of ( $\square$ ) embryo-conditioned medium compared with ( $\square$ ) control medium on rate of development and number of cells in mouse blastocysts. Embryos were cultured at low density (one embryo per $25 \mu \mathrm{l})$ from the four-cell stage in standard conditioned medium and assessed at specified times after hCG injection for stage of development, or were cultured at low density from the eight-cell stage in concentrated conditioned medium and assessed for numbers of cells in blastocyst at $104 \mathrm{~h}$ after hCG injection. Values are means of three (rate of development) or five (number of cells) independent experiments and the number of samples is shown in parentheses. $\left({ }^{*}\right) P=0.051$, $* P<0.05, * * * P<0.01$.

contains factor(s) derived from the embryos that stimulate development.

\section{Effect of exogenous PAF on development}

Embryos cultured from the four-cell stage at low density in the presence of PAF $\left(0.5 \mu \mathrm{mol} \mathrm{l^{-1 }}\right)$ initiated cavitation $(P<0.05)$ and completed zona hatching $(P<0.05)$ at a faster rate compared with controls in unsupplemented medium (Fig. 3a). PAF-treated embryos $\left(0.2 \mu \mathrm{mol} \mathrm{l}^{-1}\right)$ also had a significantly increased number of cells in the blastocyst $(P<0.02)$ and trophectoderm $(P<0.01)$ compared with controls but the number of cells in the inner cell mass was not increased $(P>0.05)$ (Fig. 3b). In contrast, embryos cultured in the presence of Lyso-PAF, an inactive metabolite of PAF, showed no evidence of stimulation of development rate $\left(0.5 \mu \mathrm{mol} \mathrm{l^{-1 }}\right)$ or increased number of cells $\left(0.2 \mu \mathrm{mol} \mathrm{I}^{-1}\right.$; Fig. 3a,b). Similarly, low density culture in Enantio-PAF, an enantiomer of PAF, did not cause an increase in the number of cells compared with control medium (Fig. 4b). These results confirm that PAF, but not related molecules, stimulates development in a manner and extent similar to both high density culture, and low density culture in embryo-conditioned medium.

\section{Effect of PAF-receptor antagonists on embryo development}

Embryos were cultured at high or low density in the presence or absence of CV-3988 or SDZ 64-412 (PAF receptor antagonists), Enantio-PAF or Lyso-PAF. Embryos were either scored for cavitation and zona hatching at appropriate times or processed for the determination of number of cells in the blastocyst.

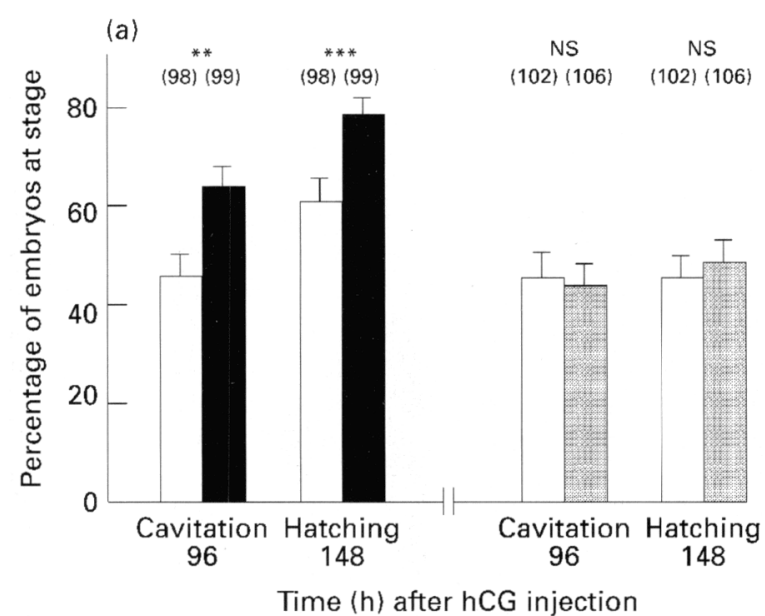

(b)

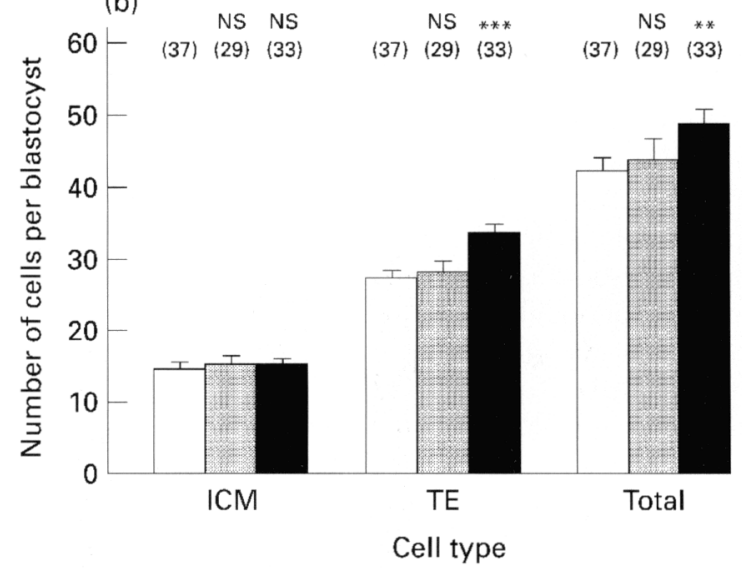

Fig. 3. Effect of platelet-activating factor (PAF) and Lyso-PAF on rate of development and number of cells in mouse blastocysts. (a) Embryos were cultured at low density (one embryo per $25 \mu \mathrm{l}$ ) from the four-cell stage in ( $\square$ ) control medium, or medium supplemented with (ם) PAF $\left(0.5 \mu \mathrm{mol} \mathrm{^{-1 }}\right)$ or (⿴囗十) Lyso-PAF $\left(0.5 \mu \mathrm{mol} \mathrm{l}^{-1}\right)$ and assayed at specified time after hCG injection for stage of development. Reagents were compared with control medium and not with each other, hence the inclusion of separate control data. (b) Embryos cultured as in (a) but in $0.2 \mu \mathrm{mol} 1^{-1}$ PAF or Lyso-PAF were assessed for the number of cells in the inner cell mass (ICM), trophectoderm (TE) or the total number of cells $105 \mathrm{~h}$ after hCG injection. Values are means of two or three independent experiments and the number of samples is shown in parentheses. $* P<0.05, * * P<0.02, * * * P<0.01, \quad N S=$ not significantly different from control.

In contrast to control embryos, the rate of development of embryos cultured from the four-cell stage in the presence of either of the receptor antagonists was not stimulated by high density culture compared with low density culture (Fig. 4a,b). Similarly, the number of cells in the blastocysts of embryos cultured at high density in the presence of antagonists was not significantly greater than those cultured at low density (Fig. 4a,b). However, although both antagonists inhibited stimulation of development rate and number of cells in the blastocyst at high density, neither was found to inhibit development or proliferation of embryos cultured at low density when compared with control embryos (Fig. 4a,b). Unlike the receptor antagonists, culture of embryos in the presence of PAF 

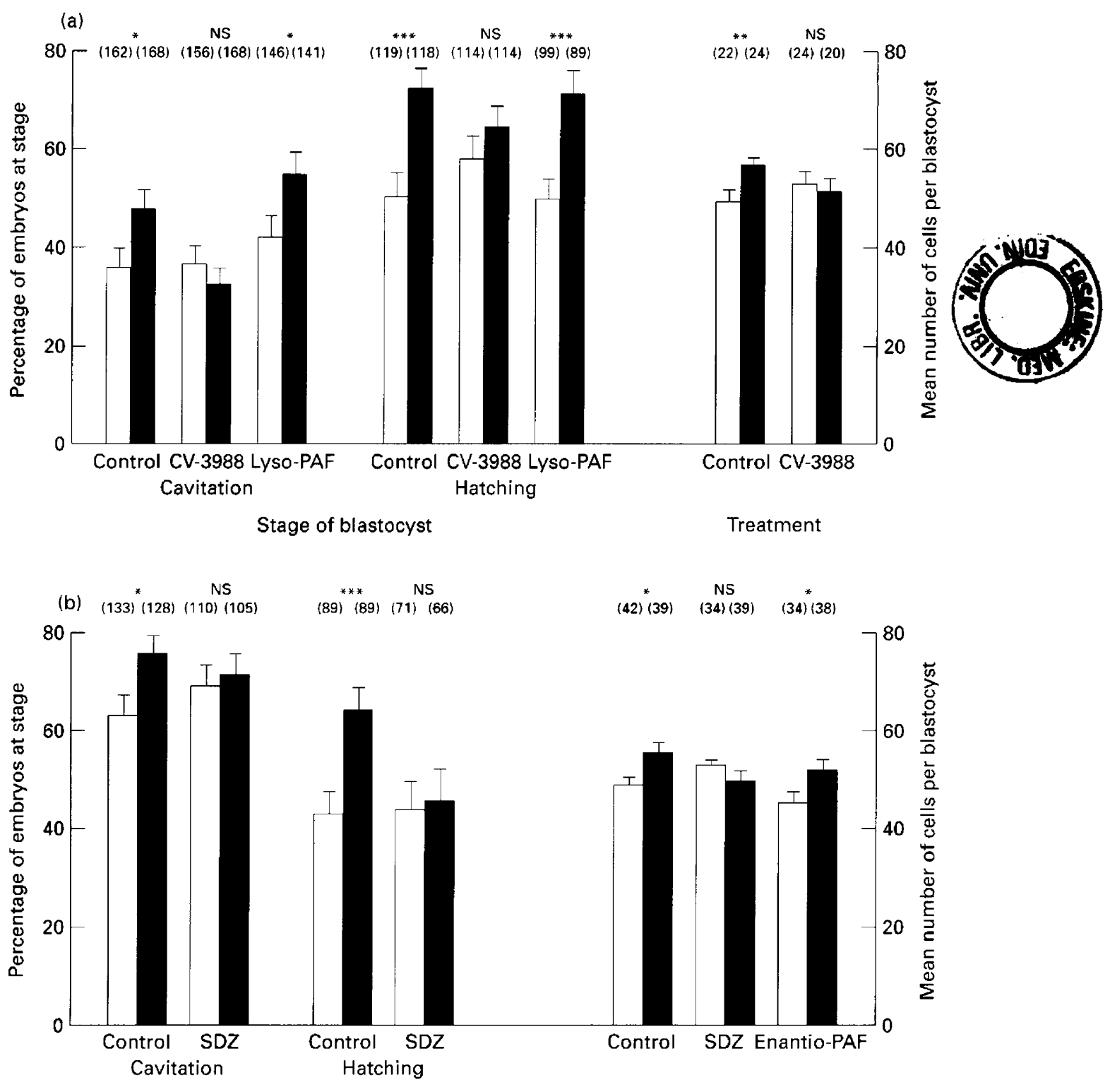

Stage of blastocyst

Treatment

Fig. 4. Effect of platelet-activating factor (PAF) receptor antagonists CV-3988 and SDZ 64-412 on rate of development and number of cells in mouse blastocysts. (a) Embryos were cultured at ( $\square$ ) low (one embryo per $25 \mu$ l medium) or $(\square)$ high (ten embryos per $25 \mu$ l medium) density from the four-cell stage in control medium or medium supplemented with CV-3988 $\left.(5 \mu \mathrm{mol}]^{-1}\right)$ or Lyso-PAF $\left(10 \mu \mathrm{mol} \mathrm{l}{ }^{-1}\right)$ and assayed at specified times after the hCG injection for stage of development and $102 \mathrm{~h}$ after hCG injection for number of cells in the blastocyst. (b) Embryos were cultured at low or high density from the four-cell stage in control medium or medium supplemented with SDZ 64-412 $\left(10 \mu \mathrm{mol} \mathrm{l}^{-1}\right)$ or Enantio-PAF $\left(10 \mu \mathrm{mol} \mathrm{l}^{-1}\right)$ and assayed at specified times after hCG injection for stage of development and $102 \mathrm{~h}$ after the hCG injection for the number of cells in the blastocyst. Values are means of three or four independent experiments and the number of samples is shown in parentheses. ${ }^{*} P<0.05,{ }^{* *} P<0.02,{ }^{* * *} P<0.01$, NS $=$ not significantly different.

analogues (either Lyso-PAF or Enantio-PAF) did not inhibit the stimulatory effect of culture at high density (Fig. 4a,b).

\section{Discussion}

Our initial experiments comparing embryo culture at high and low density confirmed the results of previous studies in mice showing density-dependent stimulation of cavitation (Wiley et al., 1986; Paria and Dey, 1990) and cell proliferation in blastocysts (Paria and Dey, 1990; Lane and Gardner, 1992). Our data also show that high density culture stimulates the rate of compaction and zona hatching and that an increase in the number of cells in blastocysts occurs within both trophectoderm and inner cell mass cell lineages. 
The simplest interpretation of this phenomenon is that embryos release stimulatory factor(s) into the medium that acts in a concentration-dependent manner to promote embryo development. We have shown that embryo-conditioned medium has a stimulatory activity since embryos cultured within it at low density display equivalent enhancement of development and proliferation to those cultured at high density in normal medium. These data suggest that any released factor(s) is at least transiently stable and capable of retaining functional activity over $24-48 \mathrm{~h}$. The data also demonstrate that the high density phenomenon cannot be explained by a mechanism requiring inter-embryonic contact, supporting the work of Lane and Gardner (1992). In other experiments, we found that embryos cultured in protein-free medium (M16 + PVP) showed advanced cavitation at high density compared with low density, indicating that the high density phenomenon is not dependent upon uptake and metabolism of exogenous protein.

The molecular nature of the prospective released factor $(\mathrm{s})$ responsible for stimulation of development at high density has not been identified. Several mammalian growth factors added to the medium have been shown to mimic the effect of high density culture and stimulate development of embryos cultured at low density (Paria and Dey, 1990). In addition, the protein metabolite taurine has been shown to stimulate preimplantation development (Dumoulin et al., 1992a, b). In our preliminary analysis of embryo-conditioned medium, no known growth factors, taurine or a change in the amino acid profile were noted ( $N$. Stoddart, unpublished observations); however, low concentrations of active molecules may go undetected.

Embryo-derived PAF is another potential candidate to explain the effect of high density culture (see Lane and Gardner, 1992; O'Neill, 1994) since it is synthesized in and secreted by early embryos, and exogenous PAF can stimulate several features of early development in mice including cell cycle progression (O'Neill, 1994), number of cells in the blastocyst and mitosis (Ryan et al., 1990b; Roberts et al., 1993), and the rate of cavitation (Minhas, 1991). In the present study, exogenous PAF, but not Lyso-PAF or Enantio-PAF, stimulated cavitation, zona hatching, the total number of cells in the blastocyst and in the trophectoderm, but not in the inner cell mass. This appears to be the first report that exogenous PAF advances zona hatching, although culture with PAF is known to stimulate implantation (Ryan et al., 1990b) for which successful zona hatching is a prerequisite. The fact that PAF appears preferentially active on the trophectoderm lineage is consistent with earlier studies showing reduced trophoblast outgrowth of mouse blastocysts cultured in vitro in the presence of PAF antagonists (Spinks et al., 1990), increased placental but not fetal masses in mouse neonates developed from embryos cultured in PAF-supplemented medium (Ryan et al., 1990b), and stimulation of trophectoderm proliferation in embryos from $\mathrm{B}_{6} \mathrm{D}_{2} \mathrm{~F}_{1} / \mathrm{J}$ mice (Roudebush et al., 1995b).

Can the stimulation of development at high density culture be explained by embryo-derived PAF (EPAF) activity? Our data argue strongly that it can. We have shown that two structurally distinct and specific PAF-receptor antagonists are able to negate the stimulatory influence of high density culture in terms of development rate and cell proliferation.
Importantly, effective concentrations of antagonists are not toxic since development of, and number of cells in, embryos cultured in their presence at low density are not impaired. In addition, high density stimulation of development is not affected by PAF control molecules. We therefore envisage that released EPAF acts in a concentration-dependent manner in culture to stimulate development via cell surface receptors. Interestingly, whilst high density culture stimulates early development in a lineage-independent manner, exogenous PAF appears to act preferentially on trophectoderm/placental lineages. This distinction may reflect differences between EPAF and PAF either in terms of activity, down-stream propagation of signalling, or accessibility to receptors. Mouse EPAF is thought to consist of one or more regulatory molecules in addition to a PAF-like component (reviewed by Adamson et al., 1991). Alternatively, other factor(s) may be released to promote proliferation of the inner cell mass during high density culture.

In conclusion, our study has provided a molecular interpretation of an intriguing phenomenon of in vitro culture of mouse embryos. Autocrine stimulation of preimplantation development has implications not only for experimental studies on animal species but also for clinical conditions of human embryo culture.

This research was supported by a SERC Quota Studentship to N. R. Stoddart and funding by The Wessex Medical Trust to A. E. Wild and T. P. Fleming and by The Wellcome Trust to T. P. Fleming. The authors thank K. Hardy and A. Handyside (Royal Postgraduate Medical School, Hammersmith Hospital) for assistance with the differential nuclear labelling protocol, D. Handley (Sandoz Research Institute, East Hanover, NJ) for the gift of SDZ 64-412, T. Sherratt and P Doncaster (University of Southampton) for advice on statistics and M. Hay for technical support and preparation of figures.

\section{References}

Adamson LM, Podsiadly B, Smart YC, Stanger JD and Roberts TK (1991) Studies on murine embryo-derived platelet-activating factor Molecular Reproduction and Development 30 207-213

Battye KM, Ammit AJ, O'Neill C and Evans G (1991) Production of platelet activating factor by preimplantation sheep embryos Journal of Reproduction and Fertility 93 507-514

Chao W and Ohlson MS (1993) Platelet-activating factor: receptors and signal transduction Biochernical Journal 292 617-629

Collier M, O'Neill C, Ammit AJ and Saunders DM (1988) Biochemical and pharmacological characterization of human embryo-derived plateletactivating factor Human Reproduction 8 993-999

Collier M, O'Neill C, Ammit AJ and Saunders DM (1990) Measurement of human embryo-derived platelet-activating factor (PAF) using a quantitative bioassay of platelet activation Human Reproduction 5 323-328

Demopoulos CA, Pinckard RN and Hanahan DJ (1979) Platelet-activating factor: evidence for a 1-O-alkyl-sn-glyceryl-3-phosphorylcholine as the active component Journal of Biological Chemistry 254 9355-9358

Dumoulin JCM, Evers JLH, Bras M and Pieters MHEC (1992a) Positive effect of taurine on preimplantation development of mouse embryos in vitro Journal of Reproduction and Fertility 94 373-380

Dumoulin JCM, Evers JLH, Bakker JA, Bras M, Pieters MHEC and Geraedts JPM (1992b) Temporal effects of taurine on mouse preimplantation development Human Reproduction 7 403-407

Fleming TP, Garrod DR and Elsmore AJ (1991) Desmosome biogenesis in the mouse preimplantation embryo Development $112527-539$

Handyside AH and Hunter S (1984) A rapid procedure for visualizing the inner cell mass and trophectoderm nuclei of mouse blastocysts in situ using polynucleotide-specific fluorochromes Journal of Experimental Zoology 231 $429-434$ 
Harper MJK (1989) Platelet-activating factor: A paracrine factor in preimplantation stages of reproduction? Biology of Reproduction 40 907-913

Lane M and Gardner DK (1992) Effect of incubation volume and embryo density on the development and viability of mouse embryos in vitro Human Reproduction 7 558-562

Minhas BS (1991) Platelet-activating factor promotes mouse embryonic growth in vitro ARTA II 321-324

Minhas BS, Zhu YP, Kim HN, Burwinkel TH, Ripps BA and Buster JE (1993) Embryonic platelet-activating factor production in the rabbit increases during the preimplantation phase Journal of Assisted Reproduction and Genetics $10366-370$

Nicolson GL, Yanagimachi R and Yanagimachi H (1975) Ultrastructural localization of lectin-binding sites on the zona pellucidae and plasma membranes of mammalian eggs Journal of Cell Biology 66 263-274

O'Neill C (1985) Partial characterization of the embryo-derived platelet activating factor in mice Journal of Reproduction and Fertility 75 375-380

O'Neill C (1994) Platelet-activating factor stimulates cell-cycle progression in 2-cell murine embryos Proceedings Australian Society of Reproductive Biology 26103

O'Neill C, Ryan JP, Collier M and Spinks NR (1989) Embryo-derived plateletactivating factor Journal of Reproduction and Fertility Supplement 37 19-27

Paria BC and Dey SK (1990) Preimplantation embryo development in vitro: cooperative interactions among embryos and role of growth factors Proceedings of the National Academy of Sciences USA 87 4756-4760

Ripps BA, Zhu YP, Burkwinkel TH, Kim HN, Buster JE and Minhas BS (1993) Platelet-activating factor production from in vitro and in vivo fertilized murine embryos is similar American Journal of Reproductive Immunology 30 101-104

Roberts C, O'Neill C and Wright L (1993) Platelet-activating factor (PAF) enhances mitosis in preimplantation mouse embryos Reproduction, Fertility and Development 5 271-279
Roudebush WE, Mathur S and Butler WJ (1995a) Anti-platelet-activating factor (PAF) antibody inhibits CFW mouse preimplantation embryo development Journal of Assisted Reproduction and Genetics 11 414-418

Roudebush WE, Duralia DS and Butler WJ (1995b) The effect of plateletactivating factor (PAF) on preimplantation mouse $\mathrm{B}_{6} \mathrm{D}_{2} \mathrm{~F}_{1} / \mathrm{J}$ embryo formation American Journal of Reproductive Immunology 33 448-449

Ryan JP, Spinks NR, O'Neill C, Ammit AJ and Wales RG (1989) Plateletactivating factor (PAF) production by mouse embryos in vitro and its effect on embryonic metabolism Journal of Cellular Biochemistry 40 387-395

Ryan JP, O'Neill C and Wales RG (1990a) Oxidative metabolism of energy substrates by preimplantation mouse embryos in the presence of plateletactivating factor journal of Reproduction and Fertility 89 301-307

Ryan JP, Spinks NR, O'Neill C and Wales RG (1990b) Implantation potential and fetal viability of mouse embryos cultured in media supplemented with platelet-activating factor Journal of Reproduction and Fertility $\mathbf{8 9} 309-315$

SAS (1988) SAS/STAT User's Guide, release 6.03 edition SAS Institute, Cary, North Carolina

Sokal PR and Rohlf FJ (1973) Introduction to Biostatistics Freeman, London

Spinks NR, Ryan JP and O'Neill C (1990) Antagonists of embryo-derived platelet-activating factor act by inhibiting the ability of the mouse embryo to implant Journal of Reproduction and Fertility $\mathbf{8 8} 241-248$

Wells XE and O'Neill C (1992) Biosynthesis of platelet-activating factor by two-cell mouse embryos journal of Reproduction and Fertility 96 61-71

Wiley LM, Yamami S and Van Muyden D (1986) Effect of potassium concentration, type of protein supplement and embryo density on the mouse preimplantation development in vitro Ferility and Sterility 45 111-119 